\title{
In vivo metabolic action of insulin-like growth factor $I$ in adult rats
}

\author{
F.Schmitz, H. Hartmann, F.Stïmpel and W. Creutzfeldt \\ Division of Gastroenterology and Endocrinology, Department of Medicine, University of Göttingen, Göttingen, FRG
}

\begin{abstract}
Summary. The acute metabolic actions of insulin-like growth factor I were studied in anaesthetized adult rats and its potency was compared to that of insulin. Following an i.v. bolus injection of insulin-like growth factor I a dose-dependent decrease of blood glucose and serum non-esterified fatty acid concentrations was noted with a potency of about $2 \%$ that of insulin. Stimulation of total body glucose disposal during euglycaemic clamping required -50 times higher insulin-like growth factor I serum concentrations to achieve an identical half-maximal response. A similar difference in potency was observed for the stimulatory action on 2-deoxyglucose uptake and on glycogen formation in skeletal
\end{abstract}

muscle. Lipogenesis in epididymal fat pads was increased dose-dependently by both hormones requiring approximately 30 times higher half-maximally effective serum concentrations of insulin-like growth factor I. These data demonstrate that insulin-like growth factor I exerted acute insulin-like metabolic actions in vivo with low potency. These effects were probably mediated via insulin receptors. A preferential stimulation of glucose metabolism in skeletal muscle was not observed.

Key words: Insulin, insulin-like growth factor I, euglycaemic clamping, glucose metabolism, lipogenesis, glycogenesis.
Insulin-like growth factor I(IGF I) is of criticalimportance for tissue growth and cellular differentiation [1]. In addition, acute metabolic actions have been described that resemble those of insulin [2]. Since IGF I is known not only to bind to its own plasma membrane receptors present on target cells but also to insulin receptors, several studies have addressed the question of whether these acute metabolic actions were attributable to interaction with IGF I receptors or insulin receptors [3]. From a variety of previous investigations different cellular mechanisms have been claimed. Whereas IGF I was shown to promote acute metabolic effects with high potency viaits own receptor in fetal rat liver cells [4], HEP-G 2 cells [5] and in a culture d murine muscle cell line [6,7], data obtained in vitro with adipocytes from adult rats [8] and humans [9] suggested metabolic actions to depend on IGF I binding to insulin receptors, despite IGF I receptors being present on these latter cells [9]. Compared to insulin the metabolic potency of IGF I was only $1-2 \%$ in adipocytes [8] while a higher potency has been described for acute metabolic actions on muscle tissues in vitro and particularly in vivo $[6,7,10-12]$. These observations prompted the view of a preferential metabolic action of IGF I on muscle cells probably mediated via the IGF I receptor present on these cells. In fact, a recent study performed in the awake adult rat seemed to support this concept since, when compared to insulin, disparate responses on hepatic glucose production and plasma non-esterified fatty acid concentrations on the one hand and on total body glucose uptake on the other hand were observed [13]. At the doses chosen, an identical stimulation of total glucose turnover was observed with both hormones, while liver and adipose tissue appeared to be affected only by insulin [13]. However, identical effects were observed simultaneously on amino acid metabolism. It should be emphasized that in this latter study each hormone was studied only at a single dose which had been observed to result in identical stimulation of total body glucose uptake. Previous in vivo studies, however, have demonstrated a decrease in plasma non-esterified fatty acid concentrations and a stimulation of lipogenesis in epididymal fat pads following i. v. bolus injection of IGF I $[14,15]$. In contrast, it has been suggested recently from work performed in conscious depancreatized dogs that IGF I and insulin have different effects on glucose kinetics and lipolysis [16]. Again, IGF I was infused as just a single dose and effects on individual tissues were not directly studied.

In the present work using anaesthetized adult rats dose response curves were obtained for the hypoglycaemic potency of insulin and IGF I, and the effects on plasma non-esterified fatty acids were studied at doses 


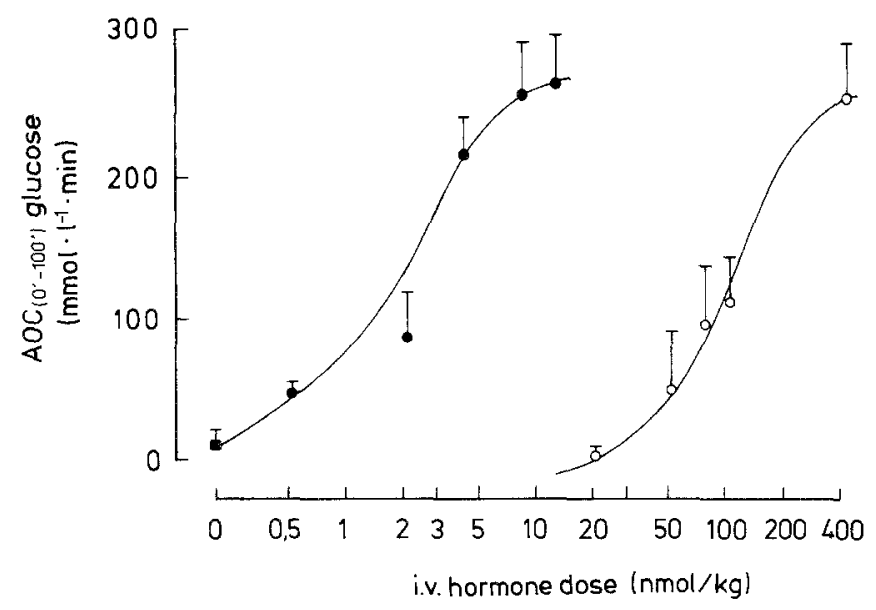

Fig. 1. Hypoglycaemic potency. Anaesthetized rats received i.v. bolus injections of insulin (--) and IGF I (O-O). Hypoglycaemia was quantitated by integrating the area over the curve (AOC) for blood glucose decrease for $100 \mathrm{~min}$ following hormone injection. Control animals ( $\boldsymbol{\nabla}$ ) received sodium chloride solution. Values are means \pm SD of at least five experiments each at individual doses
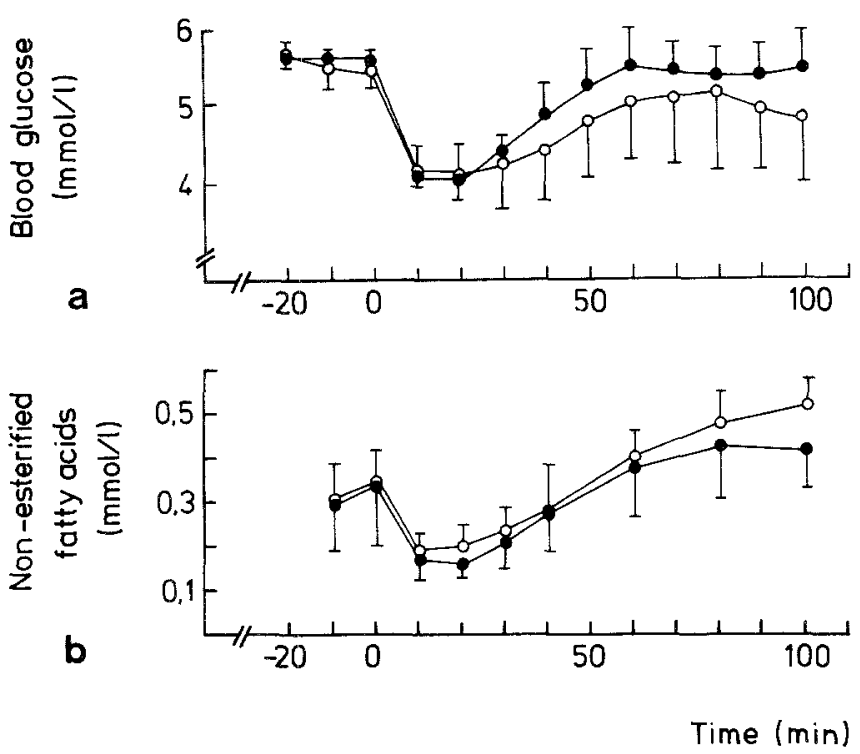

Fig. 2a,b. Anti-lipolytic action of insulin and IGF I. Anaesthetized animals received i. v. bolus injections (at time point 0 ) of $2 \mathrm{nmol} / \mathrm{kg}$

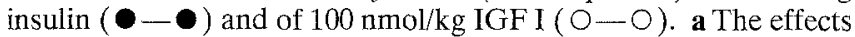
on blood glucose, $\mathbf{b}$ the effects on plasma non-esterified fatty acid concentrations. Values are means \pm SD of six experiments each

that resulted in identical hypoglycaemia. Furthermore, dose response curves were obtained for both hormones during euglycaemic clamping. In addition to the stimulation of total body glucose consumption effects on individual target tissues and on metabolic pathways, e.g. glucose uptake, glycogenesis and lipogenesis, were studied.

\section{Materials and methods}

\section{Materials}

Chemicals were reagent grade and obtained from commercial sources. Enzymes were purchased from Boehringer Mannheim (Mannheim, FRG) and porcine insulin from Serva (Heidelberg, FRG); recombinant human IGF I was a gift from Ciba Geigy (Basel, Switzerland). 2-Deoxy-(1 $\left.{ }^{3} \mathrm{H}\right)$-D-glucose (specific activity $-14 \mathrm{Ci} / \mathrm{mmol}$ ) was obtained from Amersham-Buchler (Braunschweig, FRG) and $\left(\mathrm{U}-{ }^{14} \mathrm{C}\right)$-D-glucose (specific activity $\sim 4 \mathrm{mCi} /$ mmol) from New England Nuclear (Dreieich, FRG). Insulin radioimmunoassay kit was purchased from Pharmacia (Ratingen, FRG), the anti-IGF I serum for radioimmunological determination of IGF I was a gift from Ciba-Geigy.

\section{Animals}

Male Wistar rats (212-295 g body weight) were obtained from Mus Rattus (Brunnthal, FRG). They were kept on a $12 \mathrm{~h}$ day/night cycle with free access to a standard diet (Altromin 1324, Altromin, Lage, FRG).

\section{Hypoglycaemic and anti-lipolytic action}

Food was removed from the cages $8 \mathrm{~h}$ prior to the start of the experiments at 14.00 hours, to assure absence of ingested nutrients in the intestine and to achieve a similar hepatic glycogen content. Animals were anaesthetized by i.p. injection of pentobarbital $(60 \mathrm{mg} / \mathrm{kg})$ and kept on heated covers to maintain body temperature throughout the experiments. After preparation of the right jugular vein a PVC catheter (external diameter $\sim 0.8 \mathrm{~mm}$ ), obtained from Mahrt und Hoerning (Göttingen, FRG), was inserted and positioned at the right atrium for injection of hormones and blood sampling. Following an equilibration period of $20 \mathrm{~min}$ with repeated three-fold determinations of blood glucose or non-esterified fatty acid concentrations (samples of $50 \mu \mathrm{l}$ at $10 \mathrm{~min}$ intervals), an i. v. bolus of insulin or IGF I was administered in a volume of $250 \mu \mathrm{l}(0.5,2.0,4.0,8.0$ and $12.0 \mathrm{nmol} \cdot \mathrm{kg}^{-1}$ of insulin and $20,50,75,100$ and $400 \mathrm{nmol} \cdot \mathrm{kg}^{-1}$ of IGF I in $0.9 \%$ weight/volume $(\mathrm{w} / \mathrm{v})$ sodium chloride solution containing $0.3 \%(\mathrm{w} / \mathrm{v}$ ) bovine serum albumin (BSA)). For determination of glucose subsequent blood samples $(50 \mu \mathrm{l})$ were collected at $10 \mathrm{~min}$ intervals, deproteinized in $500 \mu \mathrm{l}$ perchloric acid $(0.33 \mathrm{~mol} / \mathrm{l})$ and analysed for glucose content by the glucose-dehydrogenase method as described [17]. Hypoglycaemia was quantitated by calculating the area over the curve for individual experiments by the trapezoid method [18]. The basal line was given by the mean of the three values prior to hormone injection. For determination of non-esterified fatty acids serum samples $(30 \mu \mathrm{l})$ were obtained at time points indicated in Figure 2 and analysed enzymatically with a commercial test kit (NEFAC, Wako Chemicals, Neuss, FRG). The inserted catheters were prevented from clotting by the use of $5 \%(\mathrm{w} / \mathrm{v})$ sodium citrate.

\section{Euglycaemic clamp studies}

Animals were fasted for $24 \mathrm{~h}$, anaesthetized and kept during the experiments as described above. In addition to the venous catheter an arterial cannula was inserted into the femoral artery. According to the method of DeFronzo et al. [19] euglycaemic clamp studies were performed by primed (one-third of the respective dose per hour) continuous venous infusion $\left(1.2 \mathrm{ml} \cdot \mathrm{h}^{-1}\right.$, Unita $\mathrm{Ib}$, Braun, Melsungen, FRG) of insulin or IGFI in doses ranging from 0.5 to $13 \mathrm{nmol} \cdot \mathrm{kg}^{-1} \cdot \mathrm{h}^{-1}$ for insulin and from 25 to $200 \mathrm{nmol} \cdot \mathrm{kg}^{-1} \cdot \mathrm{h}^{-1}$ for IGF I dissolved in $0.9 \%(\mathrm{w} / \mathrm{v}) \mathrm{NaCl}$ solution containing $0.3 \% \mathrm{BSA}$ and a variable venous infusion of exogenous glucose $\left(0-1.5 \mathrm{ml} \cdot \mathrm{h}^{-1}\right.$ of a glucose solution ranging from $50-240 \mathrm{mg} / \mathrm{ml}$ ) by using a variable infusion pump (Wissenschaftliche Werkstätten der Universität Göttingen, FRG). The alterations were made empirically by adjusting the glucose infusion rate in accordance with short-term changes in arterial blood glucose concentrations measured repetitively during the experiments (Beckman Glucose Analyzer II, Beckman, München, FRG). The glucose infusion rate during the last $30 \mathrm{~min}$ of the $2 \mathrm{~h}$ clamp experiments was taken as a measure of insulin or IGF I action on whole body glucose metabolism. Blood samples $(200 \mu \mathrm{l})$ for the determination of insulin or IGF I concentrations were taken at 0 , 


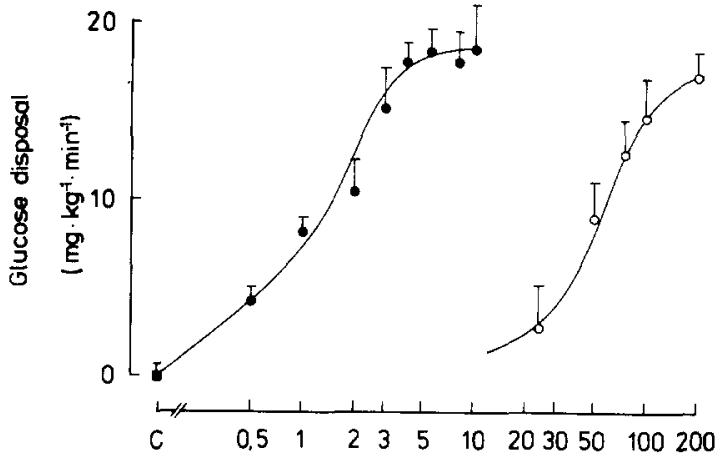

a

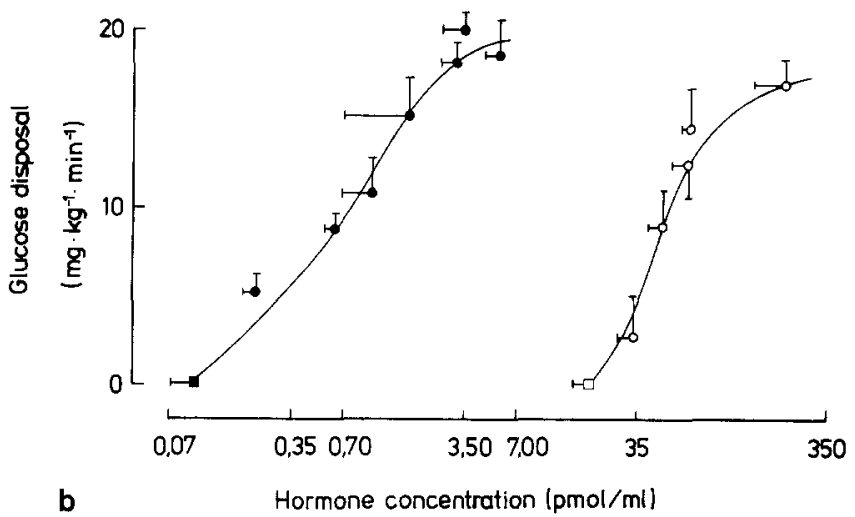

Fig. 3a,b. Stimulation of glucose disposal during euglycaemic clamping. Anaesthetized rats received i.v. infusions of insulin $(-1)$ and IGF I (O-O). Exogenous glucose was infused to maintain euglycaemia. The amount of glucose infused at steadystate conditions (90-120 min after commencement) is equivalent to whole body glucose utilisation. a Hormone infusion rates, $\mathbf{b}$ arterial hormone concentrations at steady-state. Values are means $\pm \mathrm{SD}$ of at least five experiments each at individual doses. Control animals (a) received sodium chloride solution $(0.9 \%(\mathrm{w} / \mathrm{v}))$

60,90 and $120 \mathrm{~min}$ of hormone infusion. In individual experiments the total amount of blood withdrawn did not exceed $1200 \mu$ l.

\section{Effects on individual tissues}

Insulin and IGF I action on glucose uptake in individual tissues during euglycaemic clamping were estimated by the use of labelled 2-deoxyglucose as described by Kraegen et al. [20]. In brief, animals received an i.v. bolus injection of 2 -deoxy- $\left(1-{ }^{3} \mathrm{H}\right)$-glucose $(50 \mu \mathrm{Ci}$ in a volume of $300 \mu \mathrm{l} 0.9 \%(\mathrm{w} / \mathrm{v}) \mathrm{NaCl}$ solution) at $60 \mathrm{~min}$ after the commencement of the glucose clamp with subsequent arterial blood sampling for the determination of glucose and 2-deoxyglucose concentrations. At the completion of the clamp (120 $\mathrm{min})$ tissue samples were taken from the brain, white and red parts of the gastrocnemic muscle, diaphragm, heart and epididymal fat to be analysed for the tissue accumulation of 2-deoxyglucose. Analysis and calculation of tissue glucose metabolic index ( $\left.\mathrm{Rg}^{\prime}\right)$ were performed as described in detail elsewhere [21].

Insulin and IGF I stimulatory action on incorporation of labelled glucose into lipids of epididymal fat pads and into tissue glycogen were estimated in separate experiments with $\left(\mathrm{U}^{3}{ }^{34} \mathrm{C}\right)$-glucose $(2 \mu \mathrm{Ci}$ as an i.v. injection at 60 min during euglycaemic clamping with tissue sampling at $120 \mathrm{~min}$ ) as described by Zapf et al. [15]. Lipids were extracted from adipose tissue according to Stansbie et al. [22]. Lipogenesis $(Q)$ was estimated by dividing radioactivity incorporated into lipids by the area under the blood radioactivity time curve fol- lowing bolus injection. Glycogen formation was studied by analysing individual tissues for radioactivity incorporated into glycogen as described [15]. Tissue glycogen content was determined enzymatically [23]. Glycogenesis was estimated by dividing radioactivity incorporated in to tissue glycogen by tissue glycogen content with correction for serum radioactivity following bolus injection of labelled glucose.

\section{Analytical methods}

Radioactivity in aqueous samples was counted in $10 \mathrm{ml} \mathrm{Hydroluma}$ scintillant (Baker, Deventer, The Netherlands) in a beta-counter (Mark III, Searle, Des Plaines, Ill., USA); lipids were counted using $10 \mathrm{ml}$ Instant Szint. Gel II (Canberra Packard, Zürich, Switzerland). Plasma insulin concentrations were determined by a commercial radioimmunoassay. For determintion of total IGF I concentrations $1 \mathrm{ml}$ of $0.5 \mathrm{~mol} / \mathrm{l} \mathrm{HCl}$ was added to $100 \mu \mathrm{l}$ serum and applied to SepPak $\mathrm{C}_{18}$-cartridges (Waters Assoc., Milford, Mass., USA). IGF I was eluted with methanol, lyophilized and resolved in $1 \mathrm{ml}$ of assay buffer (phosphate-buffered saline $\mathrm{pH} 7.4$ with $0.2 \%$ (w/v) human serum albumin). Free IGF I was separated from protein bound on a Sephadex G 50 column as described in detail elsewhere [15], lyophilized and resolved in $1 \mathrm{ml}$ of assay buffer. After appropriate dilution $100 \mu \mathrm{l}$ each were assayed radioimmunologically using a specific rabbit antibody. The serum samples from individual clamps obtained at steady state $(90-120 \mathrm{~min})$ were assayed in duplicate. Radioactivity was counted with a Gamma-Master 1277 (Ratingen, FRG).

\section{Statistical analysis}

Results were compared for significance using a two-tailed Student's $t$-test for unpaired data.

\section{Results}

\section{Hypoglycaemic potency and anti-lipolytic action}

Following i.v. bolus injection a dose-dependent hypoglycaemia was observed with insulin and IGF I. Figure 1 depicts the hypoglycaemic potencies calculated by integrating the area over the curve for blood glucose decrease. Compared to insulin the potency of IGF I at a half-maximally effective dose was about $2 \%$, e.g. $\sim 2 \mathrm{nmol} \cdot \mathrm{kg}^{-1}$ for insulin and $\sim 100 \mathrm{nmol} \cdot \mathrm{kg}^{-1}$ for IGF I. At these latter doses an almost identical decrease of plasma non-esterified fatty acid concentrations was observed as depicted in Figure $2(a, b) . \mathrm{NaCl}(0.9 \%(w / v))$-injected control ani-

Table 1. Stimulation of 2-deoxyglucose uptake by insulin and IGF I in individual tissues during euglycaemic clamping

\begin{tabular}{lllc}
\hline $\begin{array}{l}\text { Hormone infusion } \\
\left(\mathrm{nmol} \cdot \mathrm{kg}^{-1} \cdot \mathrm{h}^{-1}\right)\end{array}$ & \multicolumn{3}{l}{$\begin{array}{l}\text { Glucose metabolic index } \\
\left(\mu \mathrm{mol} \cdot \mathrm{min}^{-1} \cdot 100 \mathrm{~g}^{-1}\right)\end{array}$} \\
\cline { 2 - 4 } & Brain & Epididymal fat pad & Diaphragm \\
\hline Control & $8.63 \pm 1.10$ & $0.52 \pm 0.25$ & $2.38 \pm 0.80$ \\
Insulin (10) & $8.10 \pm 1.30$ & $1.57 \pm 0.41^{\mathrm{a}}$ & $30.10 \pm 5.50^{\mathrm{b}}$ \\
IGF I (200) & $6.81 \pm 0.40$ & $1.31 \pm 0.32^{\mathrm{a}}$ & $29.30 \pm 1.90^{\mathrm{c}}$ \\
\hline
\end{tabular}

Control animals received an identical infusion of $0.9 \%(\mathrm{w} / \mathrm{v}) \mathrm{NaCl}$ solution.

Data are means $\pm \mathrm{SD}$ of at least four experiments

${ }^{\mathrm{a}} p<0.05 ;{ }^{\mathrm{b}} p<0.01 ;{ }^{\mathrm{c}} p<0.001$ by Student's $t$-test compared to controls 

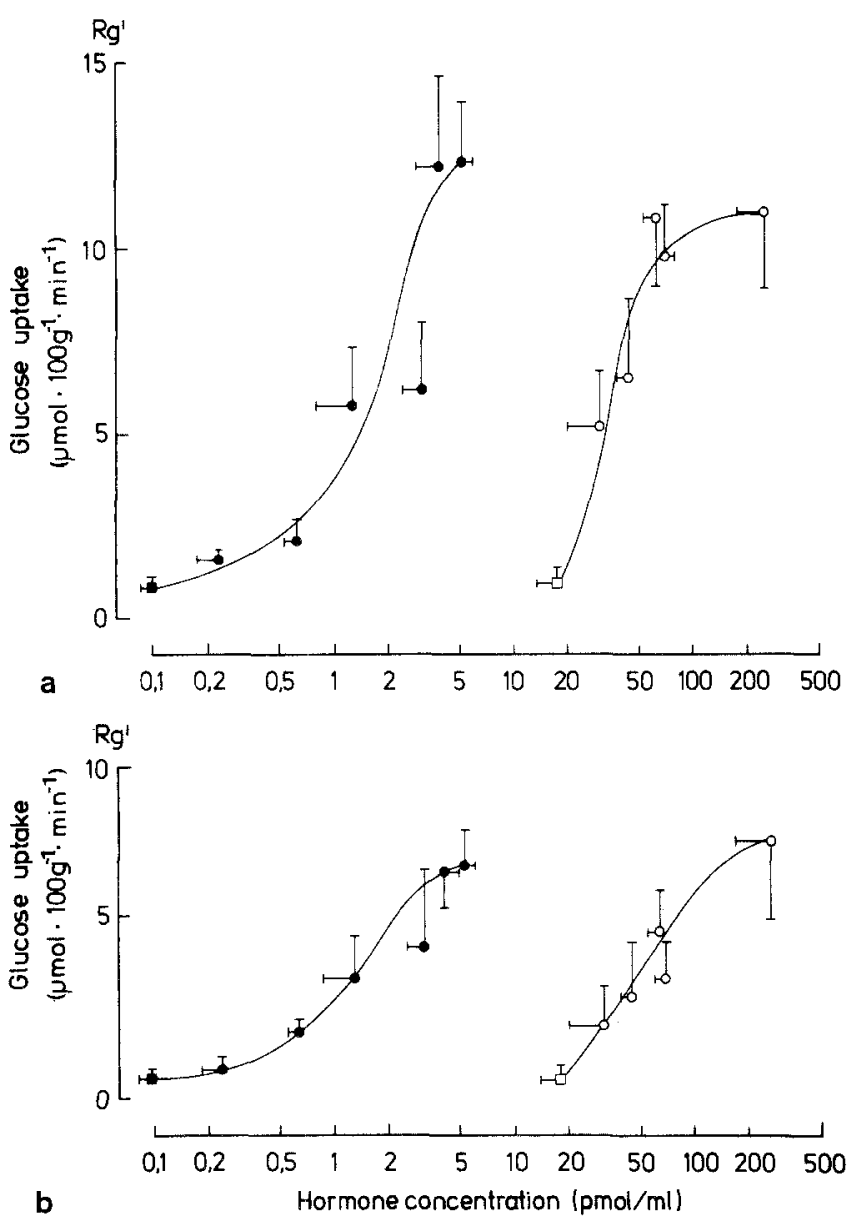

Fig. 4 a,b. Stimulation of 2-deoxyglucose uptake in red (a) and white (b) parts of gastrocnemic muscle by insulin and IGF I. Animals received i.v. infusions of insulin (-) and IGF I $(\mathrm{O}-\mathrm{O})$ as depicted in Figure 3. Arterial glucose concentrations were clamped at euglycaemic levels by means of exogenous glucose infusion. Following injection of labelled 2-deoxyglucose and subsequent tissue sampling glucose metabolic index $\left(\mathrm{Rg}^{\prime}\right)$ was calculated as described in Methods. Hormone concentrations were measured in arterial blood samples obtained at steady state during clamping (means of values measured at 90 and $120 \mathrm{~min}$ after commencement of hormone infusion). Values are means \pm SD of at least four experiments. Control animals ( $\boldsymbol{\square})$ received sodium chloride instead

mals showed neither significant changes in blood glucose nor fatty acid concentrations.

\section{Stimulation of glucose metabolism during euglycaemic clamp studies}

As demonstrated in Figure $3 \mathrm{a}$, insulin and IGF I stimulated total body glucose disposal dose-dependently with an identical maximal stimulation of $\sim 19 \mathrm{mg} \cdot \mathrm{kg}^{-1} \cdot \mathrm{min}^{-1}$. To achieve similar rates of glucose disposal approximately 30 times higher doses of IGF I were required (half-maximally effective dose of $\sim 1.5$ for insulin and $\sim 50 \mathrm{nmol}$. $\mathrm{kg}^{-1} \cdot \mathrm{h}^{-1}$, respectively). The time course for serum concentrations of the free and total portion of IGF I is given in Table 3. During the steady-state of clamp studies halfmaximally effective concentrations were in the range of
$0.8 \mathrm{pmol} / \mathrm{ml}$ for insulin and $50 \mathrm{pmol} / \mathrm{ml}$ for IGF I (Fig. $3 \mathrm{~b}$ ). Total IGF I concentrations were plotted.

\section{Stimulation of 2-deoxyglucose uptake in individual tissues}

With the exception of brain tissue, stimulation by insulin and IGF I of 2-deoxyglucose uptake in the heart, diaphragm and skeletal muscle was dose-dependent as demonstrated for the red and white part of the gastrocnemic muscle in Figure $4(\mathrm{a}, \mathrm{b})$ with half maximally effective concentrations of about $2 \mathrm{pmol} / \mathrm{ml}$ for insulin and $50 \mathrm{pmol} / \mathrm{ml}$ for IGF I. The maximal stimulation was identical for insulin and IGF I-treated rats in skeletal muscle as well as other target tissues (Table 1).

\section{Stimulation of glycogenesis}

Incorporation of labelled glucose into tissue glycogen was stimulated by insulin and IGF I with a similar difference in potency as described above. At infusion rates of insulin and IGF I that resulted in almost identical stimulation of total body glucose disposal during clamping (infusion rates of 2.5 and $100 \mathrm{nmol} \cdot \mathrm{kg}^{-1} \cdot \mathrm{h}^{-1}$ ) glycogenesis in red skeletal muscle was stimulated to a similar extent (Fig. 5a,b). Maximal stimulation was achieved with both hormones in several target tissues (Table 2).

\section{Stimulation of lipogenesis in epididymal fat pads}

As demonstrated in Figure 6, glucose incorporation in lipids was stimulated by insulin and IGF I in a dosedependent manner with identical maximal effects, but

Table 2. Stimulation of glycogen synthesis by insulin and IGF I in individual tissues during euglycaemic clamping

\begin{tabular}{llll}
\hline $\begin{array}{l}\text { Hormone infusion } \\
\left(\mathrm{nmol} \cdot \mathrm{kg}^{-1} \cdot \mathrm{h}^{-1}\right)\end{array}$ & \multicolumn{3}{l}{$\begin{array}{l}\text { Glycogen synthesis } \\
\left(\mathrm{cpm} \cdot \mu \mathrm{mol}^{-1} \cdot \mathrm{AUC}^{-1} \cdot 10^{-2}\right)\end{array}$} \\
\cline { 2 - 4 } & Liver & Red muscle & Diaphragm \\
\hline Control & $1.63 \pm 0.19$ & $0.25 \pm 0.22$ & $0.64 \pm 0.04$ \\
Insulin $(10)$ & $2.40 \pm 1.04$ & $4.61 \pm 2.50^{\mathrm{a}}$ & $14.82 \pm 5.61^{\mathrm{b}}$ \\
IGF I $(200)$ & $2.86 \pm 1.42$ & $5.27 \pm 2.61^{\mathrm{a}}$ & $13.59 \pm 3.84^{\mathrm{b}}$ \\
\hline Control animals received an identical infusion of $0.9 \%(\mathrm{w} / \mathrm{v}) \mathrm{NaCl}$ & \\
solution. & \\
$\begin{array}{l}\text { Data are means } \pm \text { SD of at least four experiments } \\
{ }^{\mathrm{a}} p<0.05 ;{ }^{\mathrm{b}} p<0.01 \text { by Student's } t \text {-test compared to controls }\end{array}$
\end{tabular}

Table 3. Time course of free and total serum IGF I concentrations during euglycaemic clamp studies

\begin{tabular}{llllll}
\hline $\begin{array}{l}\text { IGF I infusion } \\
\left(\mathrm{nmol} \cdot \mathrm{kg}^{-1} \cdot \mathrm{h}^{-1}\right)\end{array}$ & \multicolumn{4}{l}{ IGF I concentration $\left(\mathrm{pmol} \cdot \mathrm{ml}^{-1}\right)$} \\
\cline { 3 - 6 } & $\begin{array}{l}\text { Time: } 0 \\
\text { (min) }\end{array}$ & 60 & 90 & 120 \\
\hline IGF I (50) & Total & $16.95 \pm 2.7$ & $56.22 \pm 9.16$ & $53.96 \pm 7.43$ & $54.19 \pm 9.02$ \\
& Free & $0.97 \pm 0.15$ & $33.7 \pm 10.13$ & $31.82 \pm 4.92$ & $32.75 \pm 7.75$ \\
IGF I (200) & Total & $17.31 \pm 2.31$ & $241.72 \pm 43.58$ & $219.59 \pm 30.39$ & $209.87 \pm 34.7$ \\
& Free & $1.00 \pm 0.24$ & $221.41 \pm 47.45$ & $209.04 \pm 27.57$ & $186.14 \pm 9.95$ \\
\hline
\end{tabular}

Data are means \pm SD of six experiments at each infusion rate 


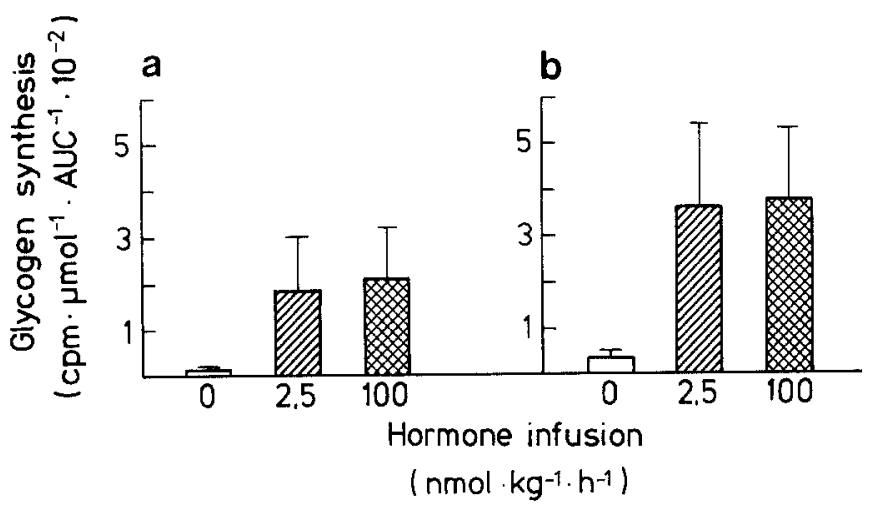

Fig. 5 a,b. Stimulation of glycogen formation in white (a) and red (b) gastrocnemic muscle by insulin and IGF I. Animals received i.v. infusions of $2.5 \mathrm{nmol} \cdot \mathrm{kg}^{-1} \cdot \mathrm{h}^{-1}$ insulin (hatched bars) and $100 \mathrm{nmol} \cdot \mathrm{kg}^{-1} \cdot \mathrm{h}^{-1}$ IGF I (crossed bars) during euglycaemic clamping. Glycogen synthesis was measured with $\left(\mathrm{U}^{1}{ }^{14} \mathrm{C}\right)$-glucose as described in Methods. Control animals (open bars) received sodium chloride solution. Values are means $\pm \mathrm{SD}$ of at least four experiments at each dose

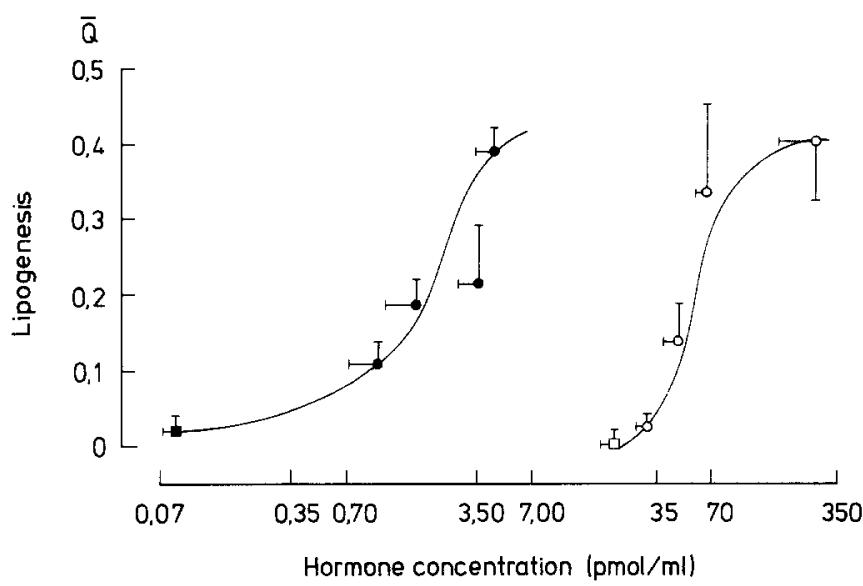

Fig. 6. Stimulation of lipogenesis in epididymal fat pads by insulin and IGF I. Animals received i.v. infusions of insulin (-) and IGF I (O-O) during euglycaemic clamping as depicted in Figure 3. Lipogenesis $(\mathrm{Q})$ was estimated with $\left(\mathrm{U}-{ }^{14} \mathrm{D}\right)$-glucose as described in Methods. Hormone concentrations were measured in arterial blood samples obtained at steady state. Control animals ( $\mathbf{\square}$ ) received sodium chloride solution. Values are means \pm SD of at least four experiments at each dose

considerably higher half-maximally effective plasma concentrations for IGF I ( 2 vs $60 \mathrm{pmol} / \mathrm{ml}$ ).

\section{Discussion}

In the present study acute metabolic actions of IGF I were observed in vivo, resembling those of insulin but with a considerably lower potency for IGF I of approximately $2 \%$ that of insulin. The hypoglycaemic action of IGF I has been observed in vivo previously in rats [15] and man [14]. In these studies only single doses were injected, thus not allowing recognition of half-maximally effective doses to estimate metabolic potency. However, in man i. v. bolus injection of about $13 \mathrm{nmol} / \mathrm{kg}$ IGF I produced an identical decrease in blood glucose as a bolus of about $1 \mathrm{nmol} / \mathrm{kg}$ in- sulin suggesting a slightly smaller difference in biopotency between IGF I and insulin than that observed in the present work.

The decrease of serum non-esterified fatty acids following insulin administration has been regarded as reflecting the anti-lipolytic action of insulin on adipose tissue. In the present work IGF I suppressed serum nonesterified fatty acid concentrations like insulin, provided that doses were applied that produced identical hypoglycaemia. This suppression has been noted in man also, however, a trend towards a more prolonged decrease following insulin administration has been observed [14]. A complete lack of anti-lipolytic action of IGF I has been reported in a recent in vivo study in awake rats [13], however only a single dose of IGF I was evaluated.

The euglycaemic hyperinsulinaemic clamp technique has been used extensively to quantify insulin effects on glucose metabolism [19]. In the present work total body glucose disposal during euglycaemic clamping was stimulated by IGF I to a similar extent of that by insulin when about 30 times higher doses of IGF I were infused. When steady-state serum hormone concentrations were measured an approximately 50 times higher IGF I concentration was required to obtain insulin-identical responses. The difference in potency when IGF I dose and IGF I serum concentration were compared might be explained by the prolonged plasma half-life of IGF I compared to that of insulin [15]. The half-maximally effective serum insulin concentrations observed during clamping in the present work for the stimulatory action on total body glucose uptake were similar to those reported by others from studies in rats [20] and man [24]. Half-maximally effective serum concentrations have not been reported for IGF I, however, it has been shown that a single dose of about $40 \mathrm{nmol} \cdot \mathrm{kg}^{-1} \cdot \mathrm{h}^{-1}$ IGF I resulted in a similar stimulation of total body glucose uptake during clamping as a dose of about $4 \mathrm{nmol} \cdot \mathrm{kg}^{-1} \cdot \mathrm{h}^{-1}$ insulin [13]. This apparently smaller difference in potency between insulin and IGF I might be attributable to different experimental conditions, e.g. duration of hormone infusion to achieve steady-state hormone concentrations, or to anaesthesia that was used in the present study. It has been demonstrated, however, that anaesthesia affected rather maximal responses during euglycaemic clamping in rats than half-maximally effective insulin concentrations [25].

It has been reported previously that IGF I stimulated glucose metabolism with higher potency in muscle cells, e.g. skeletal and cardiac muscle than in adipocytes [1012]. In the current studies metabolic potency of IGF I on skeletal muscle was observed to be similar to that on adipose tissue with half-maximally effective concentrations exceeding those of insulin 25- to 40 -fold. It should be noted, however, that the apparently higher potency of IGF I on muscle cells was observed particularly in cultured transformed cells that are known to differ in IGF I receptor expression $[6,7]$.

In addition, data obtained from perfused rat heart might be difficult to interpret since insulin is degraded to a higher extent than IGF I in this experimental condition [10]. Furthermore, early in vivo studies with rats reporting on a high potency of IGF I on muscle tissue, particularly 
diaphragm, was performed with serum derived non-suppressible insulin-like activity just at a single i. v. dose [12]. However, recent data reported using depancreatized dogs appear to be at variance with the present observations [16]. However, in this study single doses of IGF I and insulin were compared under non-clamping, hyperglycaemic and non-steady-state conditions. It might be of interest to note that differences between insulin and IGF I on hepatic glucose production on the one hand and on glucose utilization on the other hand appeared to be most pronounced immediately after the start of hormone infusion suggesting pharmacokinetic differences for the two peptides [16].

It might be proposed from the present data that at least in adult anaesthetized rats i.v. administration of IGF I stimulates glucose uptake and metabolism into glycogen in skeletal muscle with a difference in potency compared to insulin that is in the range of that for stimulatory action on adipose tissue. As observed previously rather high doses of IGF I were required to produce acute metabolic effects thus leading to highly elevated serum IGF I concentrations particularly of the free portion of the hormone that is believed to be responsible for acute metabolic actions $[14,15]$. In accordance with this view most of serum IGF I was in its free form, e.g. not bound to specific serum binding proteins at the doses used in the present work.

The molecular mechanism by which IGF I might trigger acute metabolic effects can obviously not be ascertained from the present in vivo studies. Based on the rather low potency observed which is comparable to the low affinity of IGF I to the insulin receptor, it might be deduced that in adult rats acute metabolic actions of IGF I on principal insulin target tissues could be mediated via interaction of IGF I with insulin receptors.

Acknowledgements. This study was supported by a research grant to H. Hartmann by the Deutsche Gesellschaft für Innere Medizin e. V., Wiesbaden, FRG.

\section{References}

1. Wyk JJ van (1984) The somatomedins: biological actions and physiological control mechanisms. In: LiCH (ed) Hormonal proteins and peptides, vol 12. Academic Press, New York, pp 81 125

2. Froesch ER, Zapf J (1985) Insulin-like growth factors and insulin: comparative aspects. Diabetologia 28: 485-493

3. Czech MP (1989) Signal transmission by the insulin-like growth factors. Cell 59:235-238

4. Freemark M, D'Ercole AJ, Hardwergen S (1989) Somatomedin $C$ stimulates glycogen synthesis in fetal rat hepatocytes. Endocrinology 116:2578-2582

5. Verspohl EJ, Maddux BA, Goldfine ID (1988) Insulin and insulin-like growth factor I regulate the same biological functions in HEP-G 2 cells via their own specific receptors. J Clin Endocrinol Metab 67: 169-174

6. Beguinot F, Kahn CR, Moses AC, Smith RJ (1985) Distinct biologically active receptors for insulin, insulin-like growth factor I, and insulin-like growth factor II in cultured skeletal muscle cells. J Biol Chem 260: 15982-15898

7. Cascieri MA, Chicchi GG, Hayes NS, Strader CD (1986) (Thr59)-insulin-like growth factor I stimulates 2-deoxyglucose transport in $\mathrm{BC} 3 \mathrm{H} 1$ myocytes through the insulin-like growth factor receptor, not the insulin receptor. Biochim Biophys Acta 886: $491-499$
8. Zapf J, Schoenle E, Waldvogel M, Sand I, Froesch ER (1981) Effect of trypsin treatment of rat adipocytes on biological effects and binding of insulin and insulin-like growth factors. Eur J Biochem 113: 605-609

9. Sinha MK, Buchanan C, Leggett N et al. (1989) Mechanism of IGF I-stimulated glucose transport in human adipocytes. Demonstration of specific IGF I receptors not involved in stimulation of glucose transport. Diabetes 38: 1217-1225

10. Meuli C, Froesch ER (1975) Effects of insulin and of NSILA on the perfused rat heart: glucose uptake, lactate production and efflux of 3-O-methylglucose. Eur J Clin Invest 5: 93-99

11. Poggi C, Marchand-Brustel Y le, Zapf J, Froesch ER, Freychet P (1979) Effects of binding of insulin-like growth factor I in the isolated soleus muscle of lean and obese mice: comparison with insulin. Endocrinology 105: 723-730

12. Oelz O, Jakob A, Froesch ER (1970) Nonsuppressibie insulinlike activity (NSILA) of human serum. V. Hypoglycemia and preferential metabolic stimulation of muscle by NSILA-S. Eur J Clin Invest 1: 48-53

13. Jacob R, Barrett E, Plewe G, Fagin KD, Sherwin RS (1989) Acute effects of insulin-like growth factor I on glucose and amino acid metabolism in the awake fasted rat. J Clin Invest 83: $1717-1723$

14. Guler HP, Zapf J, Froesch ER (1987) Short-term metabolic effects of recombinant human insulin-like growth factor I in healthy adults. N Engl J Med 317:137-140

15. Zapf J, Hauri C, Waldvogel M, Froesch ER (1986) Acute metabolic effects and half-lifes of intravenously administered insulinlike growth factors I and II in normal and hypophysectomized rats. J Clin Invest $77: 1768-1775$

16. Giacca A, Gupta R, Efendic S, Hall K, Skottner A, Lickley L, Vranic M (1990) Differential effects of GF-I and insulin on glucoregulation and fat metabolism in depancreatized dogs. Diabetes 39: 340-347

17. Vormbrock R (1974) UV-method with glucose dehydrogenase. In: Bergmeyer HU (ed) Methods of enzymatic analysis, vol 6 Verlag Chemie, Weinheim, pp 172 178

18. Yeh KC, Kwan KC (1978) A comparison of numerical integrating algorithms by trapezoidal, Lagrange, and spline approximation. J Pharmacokin Biopharm 6: 79-93

19. DeFronzo RA, Tobin JD, Andres R (1979) Glucose clamp technique: a method for quantifying insulin secretion and resistance. Am J Physiol 237: E 214-E 223

20. Kraegen EW, James DE, Jenkins AB, Chisholm DJ (1985) Dose-response curves for in vivo insulin sensitivity in individual tissues in rats. Am J Physiol 248: E 353-E 362

21. Kraegen EW, James DE, Storlien LH, Burleigh KM, Chisholm DJ (1986) In vivo insulin resistance in individual peripheral tissues of the high fat fed rat: assessment by euglycaemic clamp plus deoxyglucose administration. Díabetologia 29: 192-198

22. Stansbie D, Brownsey RW, Crettaz M, Denton RM (1976) Acute effects in vivo of anti-insulin serum on rates of fatty acid synthesis and activities of acetyl-coenzyme A carboxylase and pyruvate dehydrogenase in liver and adipose tissue of fed rats. Biochem J 160: 413-416

23. Keppler D, Decker K (1983) Glycogen. In: Bergmeyer HL, Bergmeyer J. Grassl M. (eds) Methods of enzymatic analysis, vol 6. Verlag Chemie, Weinheim, pp 11-18

24. Olefsky JM (1981) Insulin resistance and insulin action. An in vitro and in vivo perspective. Diabetes 30:148-161

25. Pénicaud L, Ferré P, Kande J, Leturque A, Issad T, Girard J (1987) Effect of anesthesia on glucose production and utilization in rats. Am J Physiol 252: E 365-E369

Received: 3 May 1990

and in revised form: 22 October 1990

Dr. H. Hartmann,

Medizinische Universitätsklinik

Robert-Koch-Strasse 40

W-3400 Goettingen

FRG 